\title{
Old Malay Manuscript-Based Teaching Materials for Indonesian Literature Course in Senior High School
}

\author{
Nurhayati Harahap ${ }^{1}$, Ahmad Laut Hasibuan ${ }^{2}$, IrpanApandi Batubara ${ }^{3}$ \\ \{1urhayati1@usu.ac.id, ${ }^{2}$ ahmadlauthsb@umnaw.ac.id, ${ }^{3}$ irpan.batubara@yahoo.co.id\} \\ ${ }^{1}$ Indonesian Literature, Faculty of Culture Studies University of North Sumatera Medan, Indonesia \\ ${ }^{2}$ Muslim Nusantara Al Washliyah Medan, Indonesia
}

\begin{abstract}
Indonesian Literature teaching materials have not been developed by Indonesian language teachers in high school. Teaching material is drawn from textbooks and has not been analyzed. The specific purpose of this paper is to develop teaching materials for Indonesian Literature courses based on Old Malay Texts. Old Malay Manuscripts contain many life lessons that need to be explored and to be preserved in the future. In developing teaching materials, the collection of old Malay manuscript is conducted. This research was conducted using research and development (R\&D) methods. The results of the study were Indonesian Literature subjects which teaching material derived from old Malay manuscripts. The results of the validation of teaching materials meet the element of readability and have clarity of information, the presentation has fulfilled the elements of clarity of purpose and systematicism, and the graphics use the specified type of letter (font).
\end{abstract}

Keywords - Material Development, Old Malay Manuscript , Indonesian Literature

\section{Introduction}

Indonesian Literature is one of the compulsory subjects in Indonesian High Schools. [1] mentions the function of literature etymologically is dulce et utile which means very pleasant or pleasurable, and educational. [2] add by quating Horatius's statement that literature is dulce et utile which means interesting and beneficial. Seeing the importance of the position of Indonesian Literature subjects needs to be developed based on old Malay texts. The results of preliminary studies indicate that Indonesian literary teaching materials have not been developed based on old Malay texts. Why the old Malay text? The old Malay manuscript is a relic of the time of the lamp containing many moral teachings and life learning [3]. Old manuscripts are treasures that have not been revealed intensively.

Old manuscripts are relics of the past scattered in Indonesia. One of the old texts is the Old Malay Text. Old Malay Manuscripts are manuscripts written in Malay Arabic script (Jawi). Chambert-Loir in [4] mentions that the number of Old Malay manuscripts scattered in Indonesia is approximately 4000 . 
Old Malay Manuscripts are literary works that contain messages or life lessons that need to be explored and to be preserved in the future. Based on the results of the study it was found that many Islamic teachings in the form of educational value and advice to be guided in living life [5]. This old manuscript emphasizes belief and faith in God Almighty and can be a source of enriching the main sources of Islamic law. This is in line with the opinion of [6] which states that as the process of Islamization intensified, the written tradition among the people found more momentum. Therefore, literary works that contain good moral teachings are recommended to be read, especially for high school students. In Malaysia, the importance of the Malay text has been very fundamental, since the 15 th century the country has produced recordings of more than 500 years of Malay history [7].

However, the Old Malay manuscript is now difficult to get. For this reason it is necessary to collect the manuscript to study the explicit meaning in it. As mentioned before, the Old Malay manuscript contains many religious teachings to be followed.

Based on the description above, the development of Indonesian Literature teaching materials for high school students needs to be developed. For this reason, the Old Malay Manuscripts are used as a source for the development of these teaching materials. The formulation of the problems are a) What is the content of Indonesian literary teaching materials based on old Malay manuscripts in high school? And b) How is the feasibility of Indonesian literary teaching materials based on old Malay manuscripts in high school?

\section{Research Method}

This research appled research and development design [8] stating that this research and development is oriented to a cycle that begins with the collection of preliminary information which is followed up with the process of developing a product and its development process i.e (a) preliminary study is conducted to observe the attitudes and behavior of high school students. (b) planning includes the activities of goal setting, competency formula planning, both competency standards and basic competencies, material for each competency, learning steps and evaluation. (c) development is carried out to formulate Indonesian Literature learning competencies, Indonesian Literature learning materials, and design of Indonesian Literature teaching materials for high school students in Medan.

\subsection{Data Collection}

Collecting information about the needs of literary teaching materials from students and teachers is an activity to get information on the needs of teaching materials from students and teachers. Information was obtained by giving a questionnaire. Some questionnaire questions were designed in relation to teaching materials. The results of the questionnaire cover such finding as a) First, the teacher's understanding of the function of teaching materials is quite good. The teacher believes that the function of teaching materials for educators is as a tool for educators to understand learning material, b) the understanding of literary teaching materials is still very shallow, besides the teacher also expects literary teaching materials that are easily understood by teachers and students. So, overall teachers still do not understand what is meant by literary teaching materials, but they understand the form of literary teaching materials that students like, namely literary teaching materials that can direct them about goodness through religious guidance, c) the constraints faced by teachers regarding teaching materials are quite complex in which there is no source of learning for Indonesian literature based on the Old 
Malay Text, d) the understanding of making teaching materials is still lacking because teachers have never made or compiled teaching materials in Indonesian literary literature based on Old Malay manuscript, e) teacher expectations of teaching materials can motivate and arouse students' interest to study Indonesian literature, and e) so far the teacher is only ordinary non-sourced teaching materials that are not sourced from Old Malay manuscripts so that they do not attract student learning interest, but the teacher expects the teaching material produced will be different and better than the existing ones.

\subsection{Material Development}

Teaching material is a set of material that is arranged systematically either written or not so as to create an environment / atmosphere that allows students to learn Ministry of National Education [9]. This definition implies the existence of a material arranged in such a way as to help students learn well. Development of teaching materials is an activity to bring up teaching materials that are in accordance with the demands of the curriculum. The development of materials is intended to provide teaching materials in accordance with the characteristics of students to solve problems Ministry of National Education [10]. Thus, the development of teaching materials becomes important to meet the scarcity of teaching materials needed.

\subsection{Literary Work}

A good literary work must be there to present the value of good teaching for readers in literary works, meaning literary works of high literary value if the work is able to provide entertainment and positive teaching for the reader [11]. Literary works that are only able to provide entertainment without paying attention to the value of teaching in it will feel barren. Similarly, literary works that are only able to provide teaching and are not able to provide entertainment that makes the reader comfortable and not bored to read it. Therefore, literature can be said as a means of entertainment that educates and means of educating that can entertain [12].

By reading literary works, readers can understand the traditions, habits, natural images, situations, history, and even the mindset of the people in a literary work, and practice the religious teachings contained in the works. Thus, by reading them the reader gets a sense of pleasure and comfort and knowledge that contains religious teachings, the values of truth and moral values to distinguish between good and bad to be used as provisions for life.

\section{Result and Discussion}

\subsection{Literary Teaching Material}

Literature course material is widely available in Old Malay manuscripts and can be used as teaching material in high school to enrich insights in shaping student character. The results of this study also enriched Islamic literature. Islamic literary works are currently developing in Indonesia. The rapid development of Islamic literature is relevant and in accordance with the theory of Islamic literature which is much influenced by Malay literature. According to [13], the character of Indonesian literary nuances that is Islamic is in accordance with Malaysian Malay Islamic literary theory. Thus, the realm of the study of Islamic literature becomes increasingly widespread and has a reference. 
The characteristics of learning material are closely related to graduate competency standards and content standards. Graduates' competency standards are learning goals [14]. In the 2013 curriculum learning, the objectives are the competencies that students want to achieve after they go through a learning process. Competence is a set of attitudes, knowledge, and skills that must be possessed, internalized, mastered, and actualized by students in learning [9].

In developing Indonesian literary teaching material, the fundament is based on the Old Malay manuscript that also based on poetry in Islam.

Poetry in Islam is a poem sourced from Arabic containing teachings in Islam that encourage the reader to become a man of faith and piety. Poetry is part of an old poem that is bound in the rules of rhyme. The function of poetry is not only to tell stories, but to teach in activities that are religious in nature. The characteristics of poetry include:

- Usually consists of four lines;

- rhyming a-a-a-a;

- Each line in the verse has a meaning related to the previous line.

- A poem usually tells a story.

- Syllables in each line are the same, which is 4 words and 8-12 syllables in one line [15].

The poetry implemented in Islam is the Poetry of Advice [16] which has been translated into Indonesian. Poetry of Advice is one of the Old Malay Manuscripts.

Table 1 Teaching Material For Meeting I

\begin{tabular}{|c|c|c|}
\hline NO & Cited Old Malay Text & The Meaning in English \\
\hline 1 & $\begin{array}{l}\text { Alhamdulillah pujaan Yang Esa } \\
\text { Kepada Allah S.W.T Tuhan Yang } \\
\text { Kuasa } \\
\text { Jika kurang kita periksa } \\
\text { Mengenal ketuhanan terlalu sulit }\end{array}$ & $\begin{array}{l}\text { Every time we always recite } \\
\text { Alhamdulillah and praise to Allah, the } \\
\text { Almighty God. If we don't care, we } \\
\text { will have difficulty to know God. }\end{array}$ \\
\hline 2 & $\begin{array}{l}\text { Shlawat kepada Nabi Muhammad } \\
\text { Dialah pemimpin semua ummat } \\
\text { Kepadanyalah memohon syafaat } \\
\text { Kepada Allah meminta rahmat. }\end{array}$ & $\begin{array}{l}\text { Prayers are offered to the Prophet } \\
\text { Muhammad, who is the head of all the } \\
\text { Ummah. Muhammad is a place of } \\
\text { intercession and Allah Ta'ala and is a } \\
\text { place for mercy. }\end{array}$ \\
\hline 3 & $\begin{array}{l}\text { Membaca doa jangan berhenti } \\
\text { sehingga pasti ada penyelesaian } \\
\text { Disebutkan beberapa kata yang berarti } \\
\text { Supaya yang mendengar sampai di } \\
\text { hati }\end{array}$ & $\begin{array}{l}\text { you read the prayer do not stop until } \\
\text { you are sure that the prayer is } \\
\text { finished. The words that are clearly } \\
\text { spoken can be interpreted well so that } \\
\text { the listener can understand it well and } \\
\text { can be included in his heart. }\end{array}$ \\
\hline 4 & $\begin{array}{l}\text { Membaca doa sambil berbicara } \\
\text { Di lancarkan lidah nyaringkan suara } \\
\text { Siapa yang mendengar agar gembira } \\
\text { Di dalam hatinya jadi tenang }\end{array}$ & $\begin{array}{l}\text { Reading prayer is the same as } \\
\text { speaking, wiping out our tongues and } \\
\text { making a sound, so that everyone who } \\
\text { hears it will be touched and } \\
\text { impressed. }\end{array}$ \\
\hline 5 & $\begin{array}{l}\text { Jika gelisah di dalam hatinya } \\
\text { Dapat mengingat dirinya } \\
\text { Mudah-mudahan ada obatnya } \\
\text { Agar terhinda dari durhakanya }\end{array}$ & $\begin{array}{l}\text { If the heart has been touched and } \\
\text { impressed, there will be good } \\
\text { memories left on him. These } \\
\text { memories can hopefully become a } \\
\text { medicine, which can divert or away } \\
\text { from actions that cause sin, which } \\
\text { makes it ungodly. }\end{array}$ \\
\hline
\end{tabular}


Table 2 Teaching Material For Meeting II

\begin{tabular}{|c|c|c|}
\hline NO & Cited old Malay Text & Meaning in English \\
\hline 1 & $\begin{array}{l}\text { Pertama orang berbangsa } \\
\text { Kedua bijaksana } \\
\text { Ketiga baik dan perkasa } \\
\text { Keempat berbudi dan berbahasa }\end{array}$ & $\begin{array}{l}\text { The first criterion is the offspring of } \\
\text { nobility, the second criterion is the } \\
\text { offspring of wealthy people, the third } \\
\text { criterion is good-looking and physically, } \\
\text { mentally healthy, physically strong, and } \\
\text { the fourth criterion is virtuous and well- } \\
\text { mannered. }\end{array}$ \\
\hline 2 & $\begin{array}{l}\text { Hendaklah ingat bersakit } \\
\text { Kejahatan jangan di cari } \\
\text { Maksiat jangn di gemari } \\
\text { Pekerjaan itu hendaklah ditekuni }\end{array}$ & $\begin{array}{l}\text { Always remember to avoid evil deeds; do } \\
\text { not despise immoral work, and other acts } \\
\text { that should be avoided. }\end{array}$ \\
\hline 3 & $\begin{array}{l}\text { Selalu ingat pada kejahatan } \\
\text { Jangan di buat dan selalu diingat } \\
\text { Pikirkan dahulu betul-betul } \\
\text { Kepada kebajikan pohonkan syafaat }\end{array}$ & $\begin{array}{l}\text { Bad deeds must be remembered that it } \\
\text { will create chaos. Therefore, think } \\
\text { carefully before doing it and ask for } \\
\text { intercession to be led to goodness. }\end{array}$ \\
\hline 4 & $\begin{array}{l}\text { Berbohong dan zina agar di jauhi } \\
\text { Keduanya dilarang ilahi } \\
\text { Barang siapa yang ingin melalui } \\
\text { Nantti menjadi haram di dahi }\end{array}$ & $\begin{array}{l}\text { Falsehood and adultery must be avoided } \\
\text { because these actions are forbidden from } \\
\text { the divine. Who did it, would become } \\
\text { disabled and tarnished his name for life. }\end{array}$ \\
\hline 5 & $\begin{array}{l}\text { Kepada ayah dan ibu selalu kau hormat } \\
\text { Agar bertambah kepadamu rahmat } \\
\text { Dunia akhirat kau selamat } \\
\text { Sesuatu yang kau inginkan mendapat } \\
\text { nikmat. }\end{array}$ & $\begin{array}{l}\text { Father and mother, we must respect, in } \\
\text { order to increase our grace to us, and save } \\
\text { the world hereafter, and the property we } \\
\text { get and the knowledge we demand to } \\
\text { bring pleasure. }\end{array}$ \\
\hline
\end{tabular}

The development of Indonesian Literature teaching materials based on the Old Malay Manuscript has fulfilled the minimum criteria set forth. The minimum criteria are (1) raises interest, (2) is written and designed for student use, (3) explains the objectives to be achieved, arranged based on flexible learning patterns, and (4) the structure is based on the final competency achieved, focused on training opportunities [17]. It is said to be of interest because teaching material contains moral teachings and guidelines for life written specifically used by high school students in Indonesian Literature subjects. Then, in the teaching material developed there is an explanation of the learning objectives to be achieved. Finally, the structure focuses on training opportunities, accommodates student learning difficulties, provides summaries, communicative writing styles, is packaged in an instructional process, has a mechanism for gathering feedback, and includes learning instructions.

The teaching material above has met the requirements for teaching materials according to those formulated by [9] ,namely (1) teaching material has an important role to realize equitable and high-quality education, (2) teaching material is a product of a larger process of development curriculum, (3) teaching incentives incorporate human rights principles, integrate pedagogical processes that teach peacefully to conflict resolution, gender equality, nondiscrimination, practices and other attitudes that are in line with the need to learn to live together, (4) teaching materials facilitate learning to get specific results that can be measured by considering 16 different perspectives, learning styles, and modalities (knowledge, skills, and attitudes), (5) taking into account the conceptual level, linguistic environment, background and learner needs in in forming content and designing learning models, (6) facilitating teaching materials learning that can encourage participation and experience equally 
and equitably by all learners involved in the learning process, and (7) teaching materials can be reached in terms of cost, have long durability, and can be accessed by all learners.

\subsection{Design Validation}

Design of validation activities are carried out by experts. The results of the assessment can be seen in the following table:

Table 3 Validation table of old Malay Manucript-Based Teaching Materials For Indonesian Literature Course

\begin{tabular}{|c|c|c|c|c|c|c|c|}
\hline \multirow[t]{2}{*}{ No. } & \multicolumn{2}{|r|}{ Component } & \multicolumn{5}{|c|}{ Scoring } \\
\hline & & & 1 & 2 & 3 & 4 & 5 \\
\hline \multirow[t]{7}{*}{ A. } & & Eligibility & & & & & \\
\hline & 1. & Appropriate with students' need & & & & $\sqrt{ }$ & \\
\hline & 2. & Material of the modulbroden students' horizon & & & & $\sqrt{ }$ & \\
\hline & 3. & The validity of material & & & & $\sqrt{ }$ & \\
\hline & 4. & Item tests promote critical thinking & & & & & $\sqrt{ }$ \\
\hline & 5. & Material is appropriate with modul objective & & & & $\sqrt{ }$ & \\
\hline & 6. & In accordance of value, moral, and social & & & & $\sqrt{ }$ & \\
\hline \multirow[t]{5}{*}{$\mathbf{B}$} & & Linguistics & & & & & \\
\hline & 1. & Legibility & & & & $\sqrt{ }$ & \\
\hline & & Clarity of information & & & & $\sqrt{ }$ & \\
\hline & 3. & Accordance with PUEBI & & & & $\sqrt{ }$ & \\
\hline & 4. & Effective language & & & & & $\sqrt{ }$ \\
\hline \multirow[t]{7}{*}{$\mathbf{C}$} & & Presentation & & & & & \\
\hline & 1. & Clarity of objectives & & & & $\sqrt{ }$ & \\
\hline & & Systematization & & & & $\sqrt{ }$ & \\
\hline & 3. & Motivational treatment & & & & $\sqrt{ }$ & \\
\hline & 4. & Stimulus & & & & & $\sqrt{ }$ \\
\hline & 5. & Complete information & & & & $\sqrt{ }$ & \\
\hline & & 6. Desain presentation & & & & $\sqrt{ }$ & \\
\hline \multirow[t]{3}{*}{ D } & & Graphics & & & & & \\
\hline & & 1. Font & & & & $\sqrt{ }$ & \\
\hline & & 2. Lay out & & & & $\sqrt{ }$ & \\
\hline
\end{tabular}

Note:

$1=$ highly inappropriate

$2=$ indeterminate

$3=$ moderate

$4=$ appropriate

$5=$ highly appropriate.

Validation is a process of activity to assess whether the design of the product, in this case the new teaching method rationally will be more effective than the old or not [17]. Design validation activities carried out by experts to see the elements of teaching material development in terms of the appropriateness of content, language, elements of readability and clarity of information, as well as clarity of purpose, systematic, graphic.

The results of the validation show that all the elements contained in Indonesian literary teaching materials based on the Old Malay Text are sufficient and good.

The material is developed in accordance with the needs of students, meaning that teaching materials are in accordance with the criteria expected by the users of teaching materials. This is because it has followed the format outlined. The substance of teaching material is in 
accordance with the provisions of the Indonesian Literature curriculum in high school. The knowledge contained in Indonesian literary teaching materials based on old Malay manuscripts has indicated the usefulness and insight of knowledge about Islamic poetry as an element of literary work. Poetry in Islam is a poem sourced from Arabic containing teachings in Islam that encourage the reader to become a man of faith and piety [18].

\subsection{Effectiveness of Teaching Material}

The results found that there were differences in student learning outcomes in Indonesian Language and Literature subjects between before and after learning was carried out. Learning outcomes after using teaching materials based on Old Malay script are higher than learning outcomes before using ordinary teaching materials. Teaching material developed can motivate students to learn more enthusiastically. This is in accordance with the opinion of [19] that teaching material is well packaged and applies the principles of teaching material development, namely self instructional, which makes students able to learn themselves, self contained, that is, all learning material learned is contained in one material teaching in full, stand alone, that is, the material does not depend on other teaching materials, adaptive, which has a high adaptive power to the development of science and technology, and is user friendly, that is, every instruction and information exposure that appears to be helpful and friendly to the users.

\section{Conclusion}

Based on the results of the study conclusions can be drawn as a) Indonesian literary teaching materials based on the Old Malay Manuscript have been developed in accordance with the structure outlined based on the results of the analysis of teaching material needs, examining the curriculum used, looking at learning resources and b) the results of the validation of Indonesian literary teaching materials are good. This is seen from the appropriateness of content, language, elements of legibility and information clarity. In terms of presentation, the objective and systematic elements of fulfillment have been fulfilled. Based on graphics using the type of letter (font) is specified. The other researchers are expeted to conduct the related study based another aspect.

\section{Acknowledgment}

Authors would like to thank USU Rector for funding this Research. Then, thanks are also conveyed to the organizers of International Seminar on Recent Language, Literature, and Local Cultural Studies III who accepted the article to be delivered in parallel session.

\section{References}

[1] M. Al-hafizh, "Menakar Fungsi Dulce Et Utile Karya Sastra Remaja Indonesia," In International Conference On Languages And Arts, 2012, pp. 1-2.

[2] I. Maryanah, S. Hidayat, Y. Rusyana, and A. Priyatna, "Readers' Response to Sundanese Popular Novel in 1960s to 1970s," Int. J. English Educ., vol. 3, no. 2, pp. 581-584, 2014.

[3] M. WALEY, ISA, "Manuscripts and their Importance in Islamic Cultural and Religious Studies," 
2019. .

[4] Demasyuri, "Filologi - Naskah Melayu Lama dan Naskah Jawa Kuno - Part 2,” 2019.

[5] A. L. Hasibuan and S. A. Matondang, "Creative Revitalization of Classical Text for Indonesian Character Building Education,” Asian J. Manag. Sci. Educ., vol. 6, no. 4, pp. 36-41, 2017.

[6] O. Fathurahman, "Karakteristik Naskah Islam Indonesia: Contoh dari Zawiyah Tanoh Abee , Aceh Besar," 2011.

[7] Z. Zahidah, A. Noorhidawati, and A. N. Zainab, "Exploring the needs of Malay manuscript studies community for an e-learning platform," Malaysian J. Libr. Inf. Sci., vol. 16, no. 3, pp. 31-47, 2011.

[8] Sugiyono, Metode Penelitian Kuantitatif, Kualitatif dan R\&D. Bandung: Alfabeta, 2016.

[9] M. of N. Education, "Peraturan Pemerintah Republik Indonesia Nomor 74 Tahun 2008 Tentang Guru," Jakarta, 2008.

[10] Ministry of National Education, "Panduan Pengembanagan B Ministry of National Education Bahan Ajar," Jakarta, 2008.

[11] H. Didipu, "Fungsi Sastra," 2013. .

[12] K. Yuniar, A. Rakhmawati, B. Setiawan, and K. Saddhono, "Quantum Learning Methods to Improve students' speech skill using Javanese's Krama Alus," in Journal of Physics: Conference Series, 2019, vol. 1339, no. 1, p. 12074.

[13] A. Supriadi, "Takmilah: Menuju Teori Sastra Islami," in Prosiding Seminar Internasional, 2014, vol. 14 , no. 2 , p. 242 , doi: 10.24257 /atavisme.v14i2.72.242-253.

[14] Ministry of Education and Cultural, "Permendikbud No.54 tentang Standar Kompetensi Lulusan Pendidikan Dasar dan Menengah," Jakarta, 2013.

[15] A. R. Darusman, "Bentuk Pola Baris dan Nilai Budaya. Syair Kesultanan Siak versi M. Amiroedin," J. Bhs., vol. 9, no. 2, pp. 134-142, 2014.

[16] S. Sanwani, Syair Nasehat" Ajaran Para Leluhur. Jakarta: Perpustakaan Nasional Indonesia, 1994.

[17] M. K. Azmy, A. A. Purwoko, and S. Hadisaputra, "The Development Of Chemistry Teaching Materials In The Form Of HandoutsBased ( PBL ) In Class XI IPA Madrasah Aliyah ( Ma ) Kediri District," IOSR J. Res. Method Educ., vol. 8, no. 3, pp. 71-73, 2018, doi: 10.9790/73880803037173.

[18] A. L. Hasibuan and S. A. Matondang, Sastra Indonesia yang Bersumber dari Naskah Lama. Medan: USU Press, 2018.

[19] A. Taufik and Novianti Muspiroh, "Pengembangan Modul Pembelajaran Berbasis Sains, Lingkungan, Teknologi, Masyarakat dan Islam (Salingtemasis) dalam Meningkatkan Hasil Belajar Siswa pada Konsep Ekosistem Kelas X di SMA NU (Nadhatul Ulama) Lemahabang Kabupaten," J. Sci. Educ., vol. 2, no. November, 2013. 